\title{
Ultrastructural alterations of cabrilla sea bass Serranus cabrilla liver related to experimental Gambierdiscus toxicus (dinoflagellate) ingestion
}

\author{
G. Gonzalez ${ }^{1, *}$, J. Brusle ${ }^{1}$, S. Crespo ${ }^{2}$ \\ 'Laboratoire de Biologie Marine, Université de Perpignan, Av Villeneuve, F-66860 Perpignan-Cedex, France \\ ${ }^{2}$ Laboratori de Biologia Animal, Facultat de Veterinària, Universitat Autònoma de Barcelona, E-08193 Barcelona, Spain
}

\begin{abstract}
Ultrastructural effects of dietary Gambierdiscus toxicus on the liver of cabrilla sea bass Serranus cabrilla were investigated. No fish treated with $G$. toxicus died during the experiment. A marked perisinusoidal and intercellular fibrosis occurred after algal feeding. Microvilli decreased in number and shortened at the sinusoidal and canalicular areas of the hepatocytes. Lipid accumulation was also apparent. A high number of binucleated cells, nucleolar disorganization and loss of condensed heterochromatin at the periphery of the nucleus were also found, as well as nuclear pycnosis, dilated rough endoplasmic reticulum and swollen mitochondria. This work shows that toxins produced by this dinoflagellate may be considered to be harmful to fish through diet
\end{abstract}

KEY WORDS: Gambierdiscus toxicus - Serranus cabrilla - Ciguatera - Ecotoxicology · Liver ultrastructure

\section{INTRODUCTION}

Gambierdiscus toxicus is considered as the major etiological agent of the ichthyosarcotoxism known as Ciguatera (Anderson \& Lobel 1987). G. toxicus toxins are bioaccumulated, mainly in the liver, by fish which feed on these dinoflagellates (Randall 1958, Helfrich \& Banner 1963, Yasumoto et al. 1971, 1977). G. toxicus toxins are reported to be fairly detrimental to mammals but it is established that, in the wild, there are no external differences between toxic and non-toxic fish (Banner et al. 1960).

However, it is well known that experimental ingestion of Gambierdiscus toxicus induces some macroscopical effects such as colour modifications, behavioural changes (Thalassoma bifasciatum, Labridae (Davin et al. 1986) and Chromis chromis, Pomacentridae (Durand-Clement et al. 1987)] and decrease in the liver size associated with a loss of colour of this organ [Serranus cabrilla, Serranidae (Durand-Clement

- Present address: Laboratori de Biologia Animal, Facultat de Veterinària, Universitat Autònoma de Barcelona, E-08193 Barcelona, Spain et al. 1987)]. Moreover, purified extracts of the toxins have been shown to induce changes in the muscular $\mathrm{Na}^{+}$content in Chelon labrosus [Mugilidae (Quod 1983)], epithelial degeneration of the intestine and dilatation of the gill filaments in Pomacentrus wardi and Chromis nitida [Pomacentridae (Capra et al. 1988)] and mortality in Gambusia affinis [Cyprinodontidae (Lewis 1992)]

Preliminary data on the histological effects of Gambierdiscus toxicus ingestion on Serranus cabrilla showed non-specific alterations of the hepatic structure (Amade et al. 1990). No modification was found in other organs (spleen, kidney and digestive tract; Gonzalez 1992). Taking into account that S. Cabrilla has been shown to be a suitable species for ecotoxicological testing (Gonzalez et al. 1993), the aim of this study was to describe the ultrastructural alterations of the liver of the cabrilla sea bass following experimental G. toxicus ingestion.

\section{MATERIALS AND METHODS}

Serranus cabrilla used in this experimental series were juveniles (total length $=13.52 \pm 1.47 \mathrm{~cm}$; total 
weight $=25.56 \pm 9.02 \mathrm{~g})$ collected in Banyuls-sur-Mer (France) and belonging to the 2+ age class (Bruslé 1982, Fischer et al. 1987). Gambierdiscus toxicus cultures were provided by the unity INSERM no. 303 of Villefranche-sur-Mer (France) and their toxicity characteristics were described previously $\left(2800\right.$ cells $\mathrm{mg}^{-1}$ extract, $2.33 \mathrm{MU} \mathrm{mg}^{-1}$ extract; Durand-Clement 1987).

A total of 32 fish were placed in eight 801 aquaria ( $4 \mathrm{fish}$ aquarium ${ }^{-1}$ ), in closed circulation of natural seawater and a photoperiod L:D 10:14. Salinity (mean $35 \%$ ), temperature (mean $23^{\circ} \mathrm{C}$ ), pH (mean 7.7) and nitrite concentration (lower than $0.1 \mathrm{mg} \mathrm{l}^{-1}$ ) were monitored throughout the experiment. Fish were fed a diet of marine agar and frozen mussels, according to Gonzalez et al. (1993). After 1 wk, a mixture prepared by adding Gambierdiscus toxicus (medium dose; 191.5 $\pm 71.2 \mathrm{mg} \mathrm{G}$. toxicus $\mathrm{d}^{-1}$, for 5,10 and $20 \mathrm{~d}$ ) to this basic food was administered to 12 fish. Twelve other fish were fed the basic food during the same period and constituted the control groups. Four fish were fed a higher dose of G. toxicus (high dose; $471.0 \pm 165.6 \mathrm{mg}$ $G$. toxicus $\mathrm{d}^{-1}$ ) for only $5 \mathrm{~d}$, since Durand-Clement et al. (1987) reported that $500 \mathrm{mg} \mathrm{G}$. toxicus $\mathrm{d}^{-1}$ was lethal for Chromis chromis after $3 \mathrm{~d}$. The other 4 fish were used to test a lower dose of $G$. toxicus (low dose; $59.4 \pm 15.6 \mathrm{mg} \mathrm{G}$. toxicus $\mathrm{d}^{-1}$ ) for $20 \mathrm{~d}$ (minimum time to detect $G$. toxicus toxins in the body of the fish by mouse test; Amade et al. 1990). The intoxicated food was quickly and completely consumed. After the feeding periods, fish were killed without anaesthesia.

Liver samples were fixed by immersion $\left(2.5 \mathrm{~h}\right.$ at $5^{\circ} \mathrm{C}$ ) in a fixative solution containing $3.4 \%$ glutaraldehyde buffered with sodium cacodylate and $\mathrm{CaCl}_{2}$ (550 mOs; Bruslé 1982). Samples were post-fixed in $2 \% \mathrm{OsO}_{4}$ $\left(1 \mathrm{~h}\right.$ at $\left.5^{\circ} \mathrm{C}\right)$, dehydrated in a graded acetone series and finally embedded in epon resin. Semithin sections (1 $\mu \mathrm{m}$ ) were stained with methylene blue-azur II (Richardson et al. 1960) and ultrathin sections (50 nm) with uranyl acetate in ethanol $50^{\circ}$ and lead citrate (Reynolds 1963). Observations were made using a Hitachi HU12A transmission electron microscope (TEM).

\section{RESULTS}

TEM observations showed hepatic lesions in the Serranus cabrilla intoxicated with the medium dose (191.5 $\pm 71.2 \mathrm{mg}$ Gambierdiscus toxicus $\mathrm{d}^{-1}$ ) during the 3 periods tested. The untreated group exhibited the same hepatic ultrastructure as described previously by Gonzalez et al. (1993). After $5 \mathrm{~d}$ of treatment, a marked perisinusoidal and interhepatocyte fibrosis occurred. Microvilli decreased in number and shortened (Fig. 1). Although the energy reserves of the hepatocyte were mainly constituted by glycogen, lipid accumulation of moderate to high osmiophily was also apparent (Fig. 2). After $10 \mathrm{~d}$ of intoxication, the fatty change was more evident and lipid droplets were found even in the nucleus of the hepatocyte (Fig. 3). Some myeline figures were also observed in the cytoplasm or inside the mitochondria (Fig. 3). Nuclear lesions started $10 \mathrm{~d}$ after the beginning of intoxication and were more common in the $20 \mathrm{~d}$ treated fish. These showed a high number of binucleated cells, nucleolar disorganization and loss of condensed heterochromatin at the periphery of the nucleus (Fig. 4). Hepatocytes with nuclear pycnosis, dilated rough endoplasmic reticulum (rER) and swollen mitochondria were also found (Fig. 4).

No fish treated with the high dose $(471.0 \pm 165.6 \mathrm{mg}$ Gambierdiscus toxicus $\mathrm{d}^{-1}$ ) died during experimentation. The disorganization of the sinusoidal poie of the hepatocyte was apparent, with loss of microvilli, and rupture of the endothelium of the sinusoid (Fig. 5). Within the simusoids, cellular debris and altered organelles such as mitochondria with dense matrix were found (Fig. 5). The canalicular pole of the hepatocyte was also affected, exhibiting loss of microvilli (Fig. 6). The accumulation of lipids was more apparent at this high dose (Fig. 7), but no intranuclear lipid droplets were detected. The most common nuclear malformation was a loss of the spherical regular shape (Figs. $7 \& 8$ ). Extense areas of hepatocytes with nuclear alterations, highly dilated IER and swollen mitochondria, as well as interhepatocyte fibrosis (Fig. 8) were found.

The low dose $(59.4 \pm 15.6 \mathrm{mg}$ Gambierdiscus toxicus $\mathrm{d}^{-1}$ ) induced minor changes in the liver of Serranus cabrilla after $20 \mathrm{~d}$ of intoxication. The sinusoids and the microvilli of both sinusoidal and canalicular poles were not affected. The energy stores were still constituted by glycogen, even though some lipid droplets were observable. Some hepatocytes exhibited a dilation of the rER and swollen mitochondria as well as some lipofuscin granules in the cytoplasm (Fig, 9)

\section{DISCUSSION}

The present observations showed that the experimental ingestion of Gambierdiscus toxicus induces ultrastructural alterations of the liver of Serranus cabrilla. No mortality was detected during experimentation in this fish species, even following the highest dose treatment $\left(471.0 \pm 165.6 \mathrm{mg} G\right.$. toxicus $\left.\mathrm{d}^{-1}\right)$. Mortality induced by $G$. toxicus ingestion has been reported by Durand-Clement et al. (1987) in Chromis chromis (Pomacentridae) fed for $3 \mathrm{~d}$ with $500 \mathrm{mg}$ of algae. Our data show that $S$. cabrilla is less sensitive to $G$. toxicus toxins than other fish species such as $C$. chromis. However, the severity of the hepatic lesions 

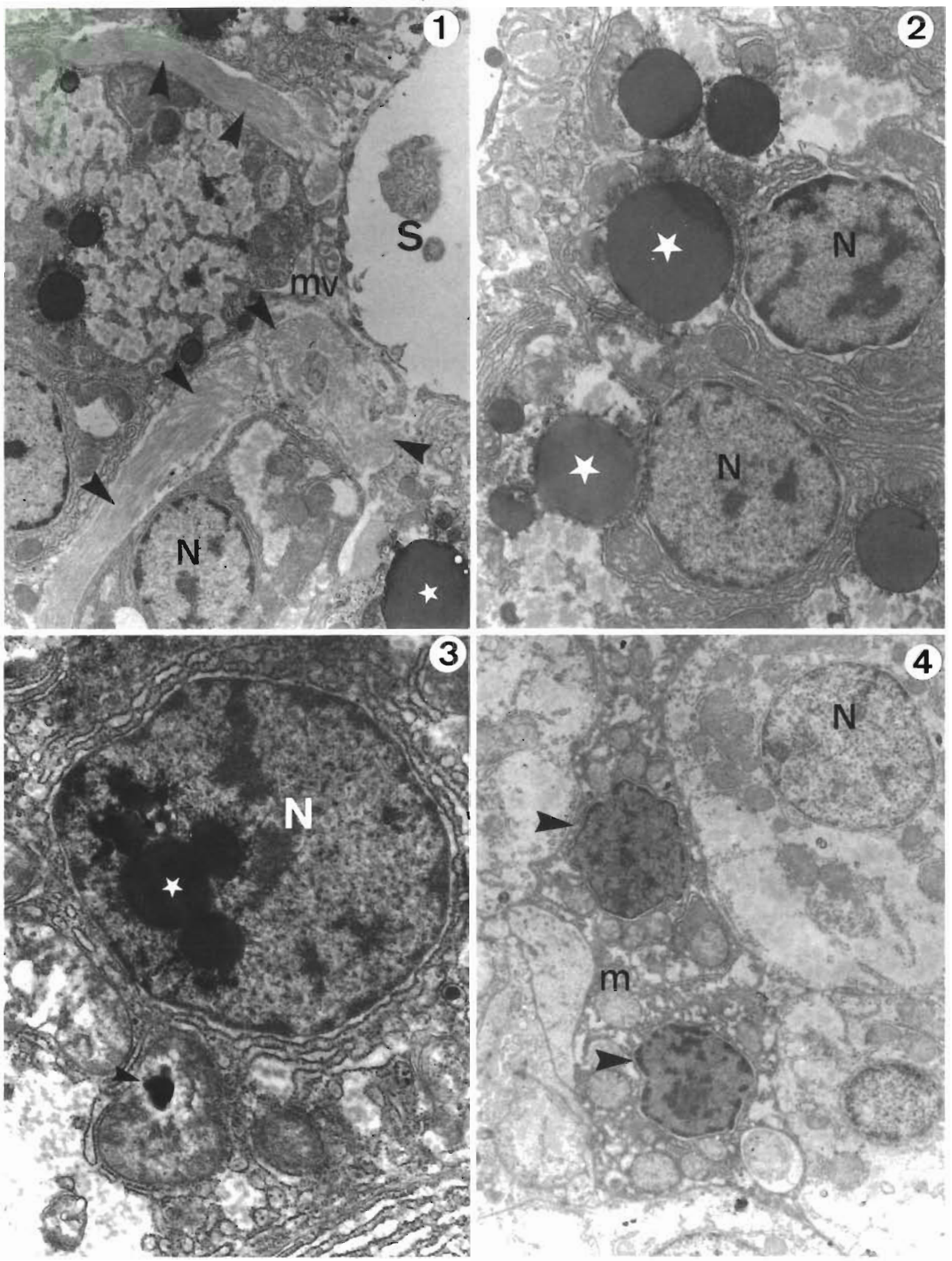

Figs. 1 to 4. Serranus cabrilla after ingesting medium dose of Gambierdiscus toxicus. Fig. 1. Liver after medium dose for $5 \mathrm{~d}$, TEM, $6900 \times$. Note the perisinusoidal and intercellular fibrosis (arrowheads) in hepatocytes with few microvilli and some lipid droplets (star). Fig. 2. Liver after medium dose for 10 d, TEM, $9100 \times$ Two hepatocytes showing lipid droplets (star) of moderate osmiophily. Fig. 3. Liver after medium dose for 10 d, TEM, $13600 \times$. Lipids (star) inside the nucleus and a mitochondrion exhibiting a myeline figure (arrowhead). Fig. 4. Liver after medium dose for $20 \mathrm{~d}$, TEM, $6500 \times$ Binucleated hepatocyte with pycnotic nucle (arrowhead) undergoing degeneration. Loss of heterochromatin and nucleolus in the nucleus of a neighbouring hepatocyte $\mathrm{m}$ : mitochondria; mv: microvilli; N: nucleus; S: sinusoid 

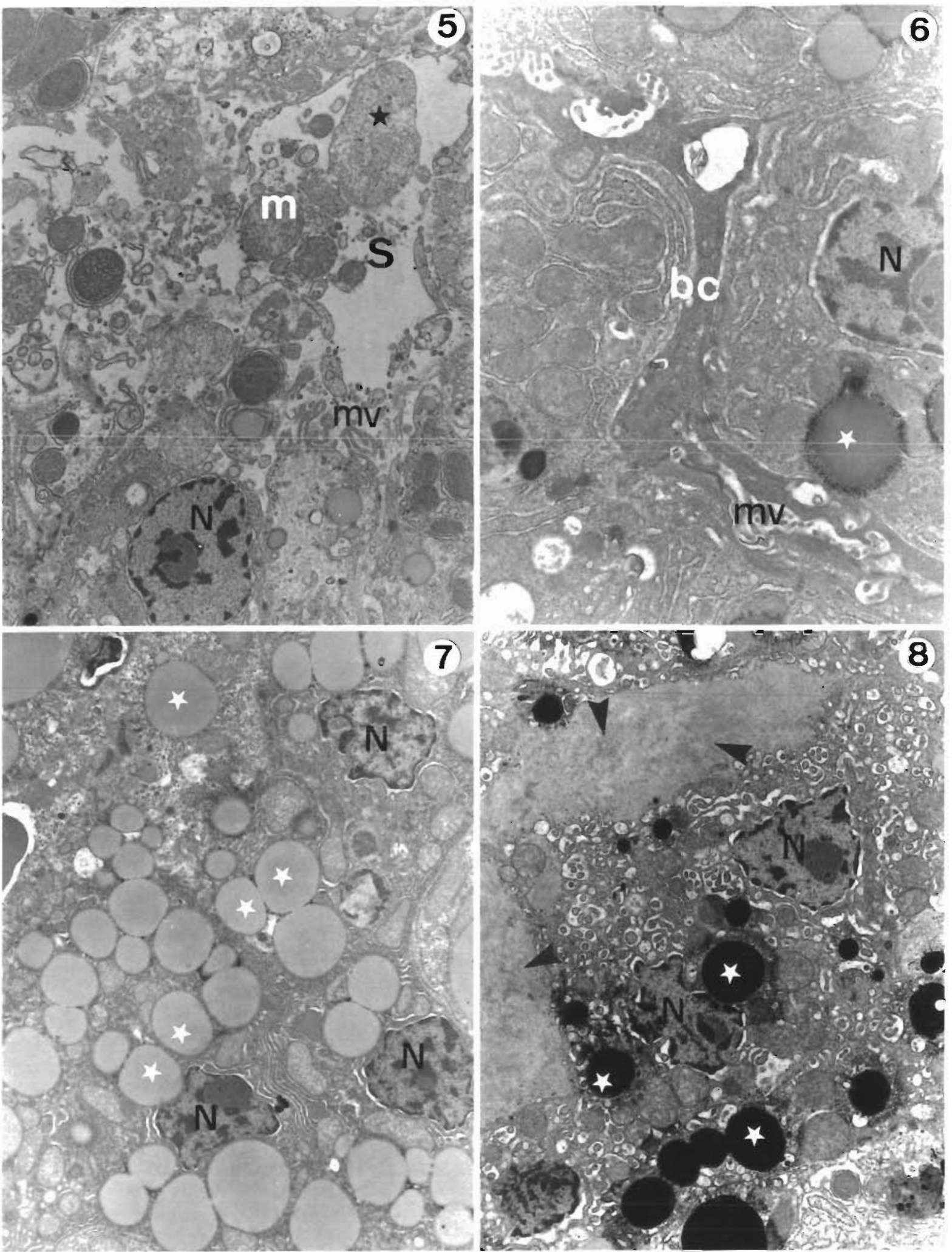

Figs. 5 to 8. Serranus cabrilla after ingesting high dose of Gambierdiscus toxicus. Liver after 5 d. Figs. 5 \& 6 . TEM, $6250 \times$ and $10400 \times$. Sinusoidal pole (Fig. 5) and bile pole (Fig. 6) are disorganized with loss of microvilli. Note the presence of mitochondria and cellular debris (star) within the sinusoid. Fig. 7. TEM, $4600 \times$. Numerous lipid droplets (star) filling the cytoplasm of cells which exhibit nuclei of abnormal shape. Fig. 8. TEM, $5950 \times$. Most of the cytoplasm of degenerating cells is occupied by a dilated rough endoplasmic reticulum and swollen mitochondria. Some very osmiophilic lipid droplets (star) as well as collagen fibres (arrowheads) are seen in this area. bc: bile canaliculum; m: mitochondria; mv: microvilli; $N$ : nucleus; S: sinusoid 


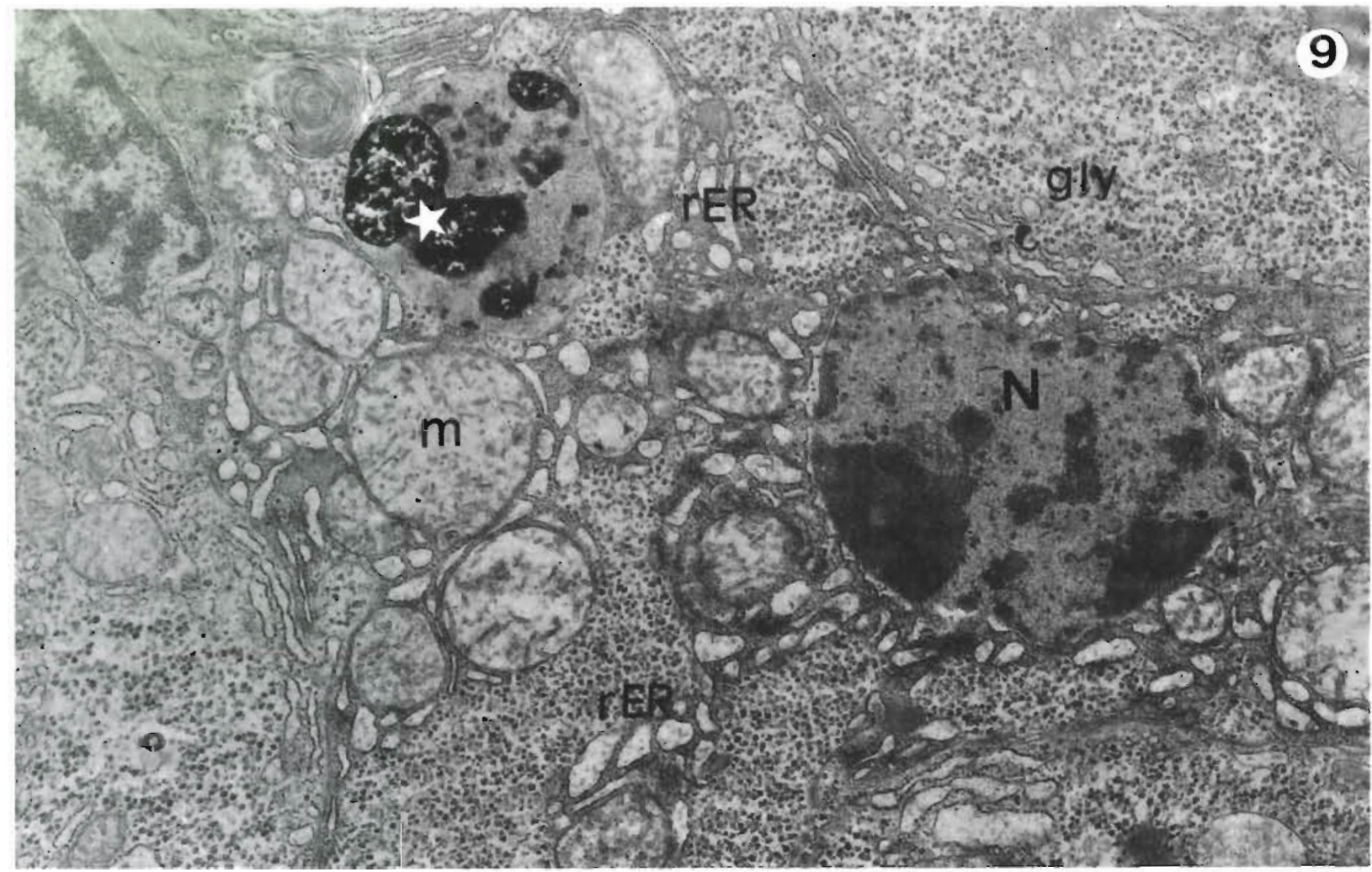

Fig. 9. Serranus cabrilla after ingesting low dose of Gambierdiscus toxicus. Liver after $20 \mathrm{~d}$, TEM, 10 500x. Hepatocyte cytoplasm is filled by glycogen. Mitochondria and rough endoplasmic reticulum are vacuolated and swollen. A lipofuscin granule (star) is also observed. gly: glycogen; m: mitochondria; N: nucleus; rER: rough endoplasmic reticulum

observed in the cabrilla sea bass after $5 \mathrm{~d}$ of intoxication with the high dose led us to believe that these toxins are not without effect on $S$. cabrilla liver

The main ultrastructural lesions of hepatocyte due to Gambierdiscus toxicus treatment are disorganization of the sinusoidal and canalicular areas and perisinusoidal fibrosis with loss of the microvilli. Numerous microvilli within the space of Disse can be considered as a good indicator of healthy hepatocyte metabolism (Byzckowska 1968, Nopanitaya et al. 1979, Ferri \& Sesso 1981, Hampton et al. 1988). Loss of microvilli of the hepatocytes and sinusoidal fibrosis have been reported in fish in association with pesticide (Biagianti 1990) or heavy metal (Gony 1990) intoxication. Our observations show that degenerating hepatocytes with dilated rER and swollen mitochondria have been found at the 3 time periods and doses tested. Degenerative processes have also been reported in the heart, ad renal glands, thymus, stomach (Terao et al. 1988, 1991), liver (Partridge \& Bergman 1982) and intestine (Coombe et al. 1987) of mouse after intoxication with purified $G$. toxicus toxins. The nucleolar lesions observed after $20 \mathrm{~d}$ of intoxication with the medium dose could be related to disturbances in the protein synthesis, since the presence of well-developed nucleoli is commonly associated with intense cellular metabolism (Ishii \& Yamamoto 1970, Byczkowska 1971).

The accumulation of lipid droplets appears to be related to the Gambierdiscus toxicus dose, being more important after the highest dose treatment and varying with time of intoxication. Fatty change is a common alteration induced by many experimental intoxications in fish (Apostol et al. 1980, Biagianti 1990) or by environmental pollution (Grawinski 1990), mainly related to liposoluble toxins. Ciguatoxins, which are liposoluble (Lewis \& Sellin 1992), could accumulate also in the hepatocyte and could modify the lipidic metabolism (Köhler 1990, Mosconi-Bac 1991). The lipid droplets observed in our study exhibited moderate to high osmiophily, related, according to the literature, to a high degree of non-saturated fatty acids (Stoeknius \& Mahr 1965). A decrease of the degree of lipid saturation was also reported by Lagraulet et al. (1975) in the surgeonfish Ctenochaetus striatus living in ciguatoxic areas.

We conclude that the ciguatoxins could induce ultrastructural hepatic disturbances in fish fed with Gambierdiscus toxicus. However, these modifications must be considered as non-specific lesions that can be induced in polluted areas by a great number of etiolog- 
ical agents (Pierce et al. 1978, 1980, Lehtinen \& Oikari 1980, Haensly et al. 1982, Matthiessen \& Roberts 1982, Gardner \& Yevich 1988, Kent 1988, Bodamer \& Murchelano 1990, Kranz \& Dethlefsen 1990) or may be related to experimental intoxications (Hinton et al. 1988, Blair et al. 1989, Köhler 1989, Holm et al. 1991). Further comparative observations in the wild, in ciguatera areas (such as the Pacific and Indian Oceans and the Caribbean Sea), may help to elucidate the effects of ciguatoxins on fish.

Acknowledgements. We thank the Unité INSERM no. 303 , France, and Dr M. Durand-Clement for the Gambierdiscus toxicus cultures. This work was performed with the financial help of the INSERM (contract no. 89.2005, France) and supported by a FPI grant from the Spanish Ministry of Education and Science to G.G.

\section{LITERATURE CITED}

Amade, P., Gonzalez, G., Rogeau, D., Puel, D. (1990). Intoxication expérimentale de Serranus cabrilla (Téléostéen, Serranidé) par Gambierdiscus toxicus (Dinoflagellé). Bull. Soc. zool. Fr. 115(2): 183-184

Anderson, D., Lobel, P. (1987). The continuing enigma of ciguatera. Biol. Bull. 17: 89-107

Apostol, S., Tudosie, A., Chera, E., Duca, E., Bordarenco, V. (1980). Recherches toxicologiques concernant l'action de quelques pesticides organochlorés sur les poissons. Trav. Mus. Hist. Nat. 'Grigore Antipa' 12: 235-238

Banner, A., Scheuer, P., Sasaki, S., Helfrich, P., Allender, C. (1960). Observations on ciguatera-type toxin fish. Ann. N.Y Acad. Sci. 90(3): 770-787

Biagianti, S. (1990). Contribution à l'étude du foie de juveniles de muges contaminés expérimentalement par l'atrazine: approche ultrastructurale et métabolique. Thèse Doct., Univ. Perpignan

Blair, J. B., Hinton, D. E., Miller, M. R. (1989). Morphological changes in trout hepatocytes exposed to acetaminophen. Mar. environ. Res. 28: 357-361

Bodamer, J. E., Murchelano, R. A. (1990). Cytological study of vacuolated cells and other aberrant hepatocytes in winter flounder from Boston Harbour. Cancer Res. 50:6744-6756

Bruslé, S. (1982). Contribution à la connaissance de la sexualité de poissons téléostéens marins gonochoriques (Mugilidés) et hermaphrodites (Serranidés). Thèse Doct., Univ. Perpignan

Byczkowska, W. (1968). Observation of the ultrastructure of the hepatic cells of the burbot (Lota lota) Zool. Pol. 18(2): $287-295$

Byczkowska, W. (1971). Observations on the ultrastructure of the hepatic cells of the chub (Leuciscus cephalus) and roach (Rutilus rutilus). Acta biol. cracov. 14: 279-284

Capra, M., Cameron, J., Flowers, A., Coombe, J., Blanton, C., Hahn, S. (1988). The effects of ciguatoxin on teleosts. In: Hutchings, P. (ed.) Proc. 6th Cong. Int. Soc. Reef Studies, Sydney, Australia, Vol. III, p. 37-41

Coombe, I., Capra, M. Flowers, A., Cameron, J. (1987). Pathological changes to the mammalian gut following administration of ciguatoxin. In: Gopalakrishnakone, P., Tan, C. K. (eds.) Proc. 1st Asia-Pacific Cong. Anim. Plant Microb. Toxins, Singapore, p. 405-410
Davin, W., Kohler, C., Tindall, D. (1986). Effects of ciguatera toxins on the bluehead. Trans. Am. Fish. Soc. 115: $908-912$

Durand-Clement, M. (1987). Study of production and toxicity of cultured Gambierdiscus toxicus. Biol. Bull. 172: 108-121

Durand-Clement, M., Amade, P., Puiseux-Dao, S. (1987). Induction of toxicity in fishes fed with cultures of the ciguateric dinoflagellate Gambierdiscus toxicus. In: Stadler, T., Karamanos, Y., Verdus, M. C., Mollion, J., Christiaen, D. (eds.) 4th Int. Meeting Soc. Algol. Appl. Villeneuve d'Ascq, France, p. 19

Ferri, S., Sesso, A. (1981). Ultrastructural study of the endothelial cells in teleost liver sinusoids under normal and experimental conditions. Cell Tiss. Res. 219: 649-657

Fischer, W., Bauchot, M., Schneider, M. (1987). Fiches FAO d'identification des espèces pour les besoins de la pêche, Vol II. FAO, Rome, p. 761-1530

Gardner, G. R., Yevich, P. P. (1988). Comparative histopathological effects of chemically contaminated sediment on marine organisms. Mar. environ. Res. 24: 311-316

Gony, S. (1990). Etude expérimentale de l'action du cadmium sur les juivériles de l'anguille curopéenne: analyse structurale et fonctionelle de certains organes-cibles. Thèse Doct., Univ. Paris VI

Gonzalez, G. (1992). Contribution à la connaissance des processus ciguatériques. Thèse Doct., Univ. Perpignan

Gonzalez, G., Crespo, S., Bruslé, J. (1993). Histo-cytological study of the liver of the cabrilla sea bass, Serranus cabrilla (Teleostei, Serranidae), an available model for marine fish experimental studies. J. Fish Biol. 43: 363-373

Grawinski, E. (1990). State of investigations on the etiopathogenesis of fish from the Polish fishery zone in the Baltic Sea. Rep. Sea Fish. Inst. 22: 107-119

Haensly, W., Neff, J., Sharp, J., Morris, A., Bedgood, M., Boem, P. (1982). Histopathology of Pleuronectes platessa from Aber Wrac'h and Aber Benoit: long-term effects of the Amoco Cadiz crude oil spill. J. Fish Dis. 5: 365-391

Hampton, J. A., Lantz, R. C., Goldblatt, P. J., Lauren, D. J., Hinton, D. E. (1988). Functional units in rainbow trout (Salmo gairdneri, Richardson) liver: II. The biliary system. Anat. Rec. 221: 619-634

Helfrich, P., Banner, A. (1963). Experimental induction of Ciguatera toxicity in fish through diet. Nature 197 : 1025-1026

Hinton, D. E., Laurence, D. J., Teh, S. J. (1988). Cellular composition and ultrastructure of hepatic neoplasms induced by diethylnitrosamine in Oryzias latipes. Mar. environ. Res. 24: $307-310$

Holm, G., Norrgren, L., Linden, O. (1991). Reproductive and histopathological effects of long-term experimental exposure to bis (tributylin) oxide (TBTO) on three spined stickleback, Gasterosteus aculeatus L. J. Fish Biol. 38: 373-386

Ishii, K., Yamamoto, K. (1970). Sexual differences of the liver cells in the goldfish. Carassius auratus. Bull. Fac. Fish. Hokkaido Univ. 21(3): 161-166

Köhler, A. (1989). Regeneration of contaminant-induced liver lesions in flounder experimental. studies towards the identification of cause-effect relationships. Aquat. Toxicol. 14: 203-232

Köhler, A. (1990). Identification of contaminant-induced cellular and subcellular lesions in the liver flounder (Platichthys flesus L.) caught at differently polluted estuaries. Aquat. Toxicol. 16: 271-294

Kent, M. L. (1988). Suspected toxicopathic hepatic necrosis and megalocytosis in pen-reared Atlantic salmon Salmo salar in Puget Sound, Washington, USA. Dis. aquat. Org. 4: $91-100$ 
Kranz, H., Dethlefsen, V. (1990). Liver anomalies in Limanda limanda from the southern North Sea with special consideration given to neoplastic lesions. Dis. aquat. Org. 9: $171-185$

Lagraulet, J., Beziat, G., Cuzon, G., Polonovski, J. (1975). Etude comparée des acides gras extraits de poissons Ctenochaetus striatus provenant de zones toxicogènes et non toxicogènes du lagon de Tahiti. Bull. Soc Path exot. 66(1): $235-239$

Lehtinen, K., Oikari, A. (1980). Subletal effects of kraft pulp mill waste water on the perch, Perca fluviatilis, studied by rotatory-flow and histological techniques. Acta zool. fenn. 17: $255-259$

Lewis, R. J. (1992). Ciguatoxins are potent ichthyotoxins. Toxicon 30(2): $207-211$

Lewis, R. J., Sellin, M. (1992). Multiple ciguatoxins in the flesh of fish. Toxicon 30(8): 915-919

Matthiessen, P., Roberts, R. J. (1982). Histopathological changes in the liver and brain of fish exposed to endosulfan insecticide during tsetse fly control operations in Botswana. J. Fish Dis. 5: 153-159

Mosconi-Bac, N. (1991). Effets de l'alimentation sur les caractères structuraux et métaboliques du foie de loup, Dicentrarchus labrax, en aquaculture. Thèse Doct., Univ. Perpignan

Nopanitaya, W., Aghajanian, J., Grisham, J. W., Carson, J. L. (1979). An ultrastructural study on a new type of hepatic perisinusoidal cell in fish. Cell Tissue Res. 196: 249-261

Partridge, L., Bergman, J. (1982). Effects of maitotoxin on the ultrastructure of cultured rat hepatocytes. Tex. Soc. Elect. Microscopy 13(4): 24

Pierce, K., McCain, B., Wellings, S. (1978). Pathology of hepatomas and other liver abnormalities in English sole from the Duwamish river estuary. Seattle, Washington. J. Natn Cancer Inst. 60(6): 1445-1453

Responsible Subject Editor: W. Körting, Hannover, Germany
Pierce, K., McCain, B., Wellings, S. (1980). Histopathology of abnormal livers and other organs of the stary flownder Platichthys stellatus from the estuary of the Duwamish river. J. Fish Dis. 3: 81-91

Quod, J. (1983). Action de la ciguatoxine sur l'équilibre de distribution hydroionique et sur la perméabilité au $\mathrm{Na}^{+}$du muscle blanc d'un téléostéen, Chelon labrosus. D.E.A. Univ. Bordeaux I

Randall, J. (1958). A review of ciguatera, tropical fish poisoning, with a tentative explanation of its cause. Bull. mar Sci. Gulf Caribb. 8(3): 236-267

Reynolds, E. (1963). The use of the lead citrate at high pH as an electron opaque stain in electron microscopy. J. Biophys. Biochem. Cytol. 17: 208-212

Richardson, K., Jarret, L., Finke, E. (1960). Embedding in epoxy resin of ultrathin sectioning in electron microscopy. Stain Technol. 35: 313-323

Stoecknius, W. Mahr, S. (1965). Studies on the reaction of osmium tetroxyde with lipids and related compounds. Lab Invest. 14: 458

Terao, K., Ito, E., Oarada, M., Ishibashi, Y., Legrand, A., Yasumoto, T (1991). Light and electron microscopic studies of pathologic changes induced in mice by ciguatoxin poisoning. Toxicon 29(6): 633-643

Terao, K., Ito, E., Sakamaki, Y., Igarashi, K., Yokohama, A., Yasumoto, T. (1988). Histopathological studies of experimental marine toxin poisoning. 2. The acute effects of maitotoxin on the stomach, heart and lymphoid tissues in mice and rats. Toxicon 26(4): 395-402

Yasumoto, T., Bagnis, R. Thevenin, S., Garcon, M. (1977). A survey of comparative toxicity in the food chain of ciguatera. Bull. Jap. Soc. scient. Fish. 43(8): 1015-1019

Yasumoto, T., Hashimoto, Y., Bagnis, R., Randall, J., Banner, A. (1971). Toxicity of the surgeonfishes. Bull. Jap. Soc. scient. Fish. $37(8)$ : $724-734$

Manuscript first received: July 23, 1993

Revised version accepted: November 20, 1993 